This item was submitted to Loughborough's Research Repository by the author.

Items in Figshare are protected by copyright, with all rights reserved, unless otherwise indicated.

\title{
Performance indicators for 'micro-projects' in developing countries
}

PLEASE CITE THE PUBLISHED VERSION

PUBLISHER

(C) Routledge / Taylor \& Francis

LICENCE

CC BY-NC-ND 4.0

\section{REPOSITORY RECORD}

Sohail, M., and Andrew N. Baldwin. 2019. "Performance Indicators for 'micro-projects' in Developing Countries". figshare. https://hdl.handle.net/2134/3855. 
This item was submitted to Loughborough's Institutional Repository (https://dspace.lboro.ac.uk/) by the author and is made available under the following Creative Commons Licence conditions.

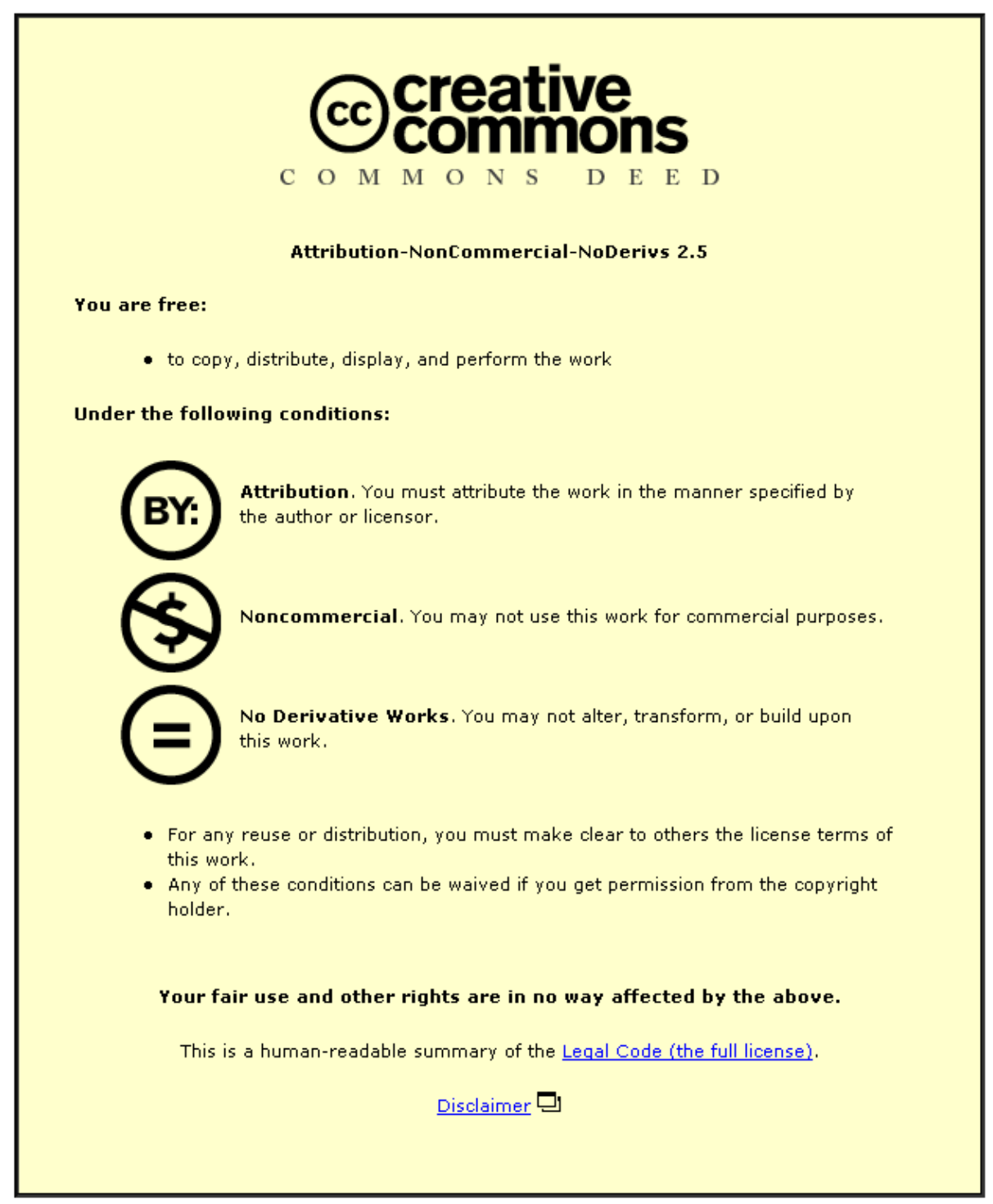

For the full text of this licence, please go to: http://creativecommons.org/licenses/by-nc-nd/2.5/ 


\title{
PERFORMANCE INDICATORS FOR 'MICRO - PROJECTS’ IN DEVELOPING COUNTRIES
}

\author{
M. Sohail and A. N. Baldwin \\ Department of Civil and Building Engineering \\ Loughborough University \\ Loughborough \\ Leicestershire LE11 3TU \\ Department of Building and Real Estate \\ The Hong Kong Polytechnic University \\ Hung Hom, Kowloon, \\ Hong Kong, P.R China
}




\title{
PERFORMANCE INDICATORS FOR 'MICRO - PROJECTS’ IN DEVELOPING COUNTRIES
}

\begin{abstract}
The majority of public works contracts undertaken in developing countries have a total cost of less than US\$15,000. They include the provision of enhanced water and sanitation, access ways and pavements, small community buildings and solid waste related construction. We term these projects, 'micro-projects'. There is a general lack of information for such projects. This paper describes the development and testing of sixty seven performance indicators for use on 'micro-projects'. They include not only general performance indicators but also indicators for inter-organisational and socioeconomic issues. These indicators are based on data from a total of over 800 microprojects undertaken in developing countries. For each indicator we provide a statement of why the indicator was selected, the key sources of information, and how to determine the indicator. Examples of the use of the indicators are also presented.
\end{abstract}

Keywords: urban infrastructure, performance indicators, developing countries, microcontracts. 


\section{Introduction}

By 2020 more than half of the world's population will be living in urban areas (UNCHS 2001). The United Nations Centre for Human Settlements (UNCHS, 1987; 1996) suggests that in many cities between 40 to $50 \%$ of the population live in slum or squatter settlements and lack basic services. The provision of urban services to city dwellers, in both formal and informal settlements, is therefore one of the biggest challenges faced by public sector urban managers in developing countries.

The provision of urban services includes infrastructure projects which vary in size from major capital projects to small scale works. Size is of course relative. The World Bank (2000) refers to ‘small’ scale projects as those projects costing less than US\$10 million. However many small scale projects have a total cost of less than US\$15,000. Projects of this size may be referred to as 'micro-projects'. They have been the focus of the research reported in this paper because the majority of public works projects undertaken in developing countries are of this size (Sohail, Miles and Cotton, 2002). The nature of these projects includes the procurement of water and sanitation, access/ pavements, solid waste related construction and small community buildings at neighbourhood level. These contracts are the 'backbone' of economic development in developing, i.e. non OECD, countries.

There is a general lack of performance related information for infrastructure projects within developing countries. The main reason for this is the lack of available data. This is particularly so with respect to micro-projects. At the outset of this research there were no performance yardsticks or indicators available for monitoring the 
procurement and the completion of such projects. The principal challenge of this research was to address this issue.

The research reported in this paper is based on data from a total of 800 'microcontracts' awarded by urban local authorities, and Non-Governmental Organisations (NGOs) in South Asia (specifically, India, Pakistan and Sri Lanka). These projects were procured under both traditional selective tendering methods and new methods of procurement such as community partnering.

This paper describes the development and use of 67indicators for use on microprojects. These indicators cover the procurement, execution and completion of the works; inter-organisational co-operation and partnership indicators; and socioeconomic indicators. Details of each of these indicators are provided, together with an explanation of why they were selected, the key sources of information required for performance measurement, how they are used and also additional comments and notes.

The size of micro-projects means that it is not always practical to monitor and control such projects in the same way as larger construction projects. There is a much greater emphasis on a retrospective review of the project and an analysis of what happened, what was different from similar projects, and how the lessons learned can be applied to future projects. The indicators have been used both to monitor progress and to assess the effectiveness of the procurement process. To show how the indicators produced may be used two examples of this type of analysis are included. General principles identified from the testing of the indicators are also provided. The conclusions include an indication of areas for future work. 


\section{Research methodology}

The indicators listed in this paper were produced over a six year period. The first stage of the research involved the collection of background information through a review of the literature. This revealed information on monitoring and control of small, medium and large construction projects but little information on 'microprojects'. Whilst some indicators, (e.g. cost, time, quality etc) were clearly important for any size of project, no published research was found comprehensively identifying the wide range of appropriate indicators required.

The literature review was therefore followed by interviews with people with experience of such projects: contractors, engineers, representatives of insurance companies, and representatives of financial institutions. These people were selected on the basis of their experience in urban infrastructure procurement in low-income countries. A total of 125 single experts contributed their views on a one-to-one basis. Data were also collected via workshops/group meetings. Thirty such meetings were conducted. These meetings included people with extensive combined experience. (The total professional experience of one group of 12 officials was 209 years, with a mean of 14.5 years and a standard deviation of 7.3. This was typical of the experience brought to the meetings.)

The interviews were conducted as semi-structured interviews comprising a series of open-ended questions designed to elicit the key issues in the successful completion of 'micro-projects'. The one-to-one interviews were taped to allow a detailed analysis of the interviewees' responses. The group interviews were conducted by a facilitator who collated the overall views of those present. (Sample questions from both the oneto-one interviews and the group interviews are shown in Appendix I. ) 
In addition to the data collected from the interviews, extensive use was also made of information on current and past micro-projects which was provided by the experts interviewed and government officials.

From the published information, the interviews, and the project data, a preliminary list of indicators was produced. This required the researchers to triangulate the findings across the range of data collated from the different actors involved, to ensure that the indicators identified were not biased to one particular perspective. The indicators were presented as a list stating clearly: each indicator, a statement as to why it had been selected and the units of measurement to be used. A total of 93 indicators were produced.

The validation of these indicators was obtained from a different group of 200 independent officials. The lists of indicators were distributed via post, e-mail and through key partners. Each recipient was requested to comment on the list and suggest improvements, giving the reasons why they considered the amendments to be required. Their comments were analysed and the original list amended to reflect the wider input. A revised list of 67 indicators was then available for field trials.

The indicators were then used on a trial basis on 25 micro-projects in India, Pakistan, and Sri Lanka. Following successful testing they were then used widely in these countries over a four year period.

Over a six year period the indicators were therefore developed, tested, and refined to give the final list included in this paper. They have now been tested on a total of over 800 micro-projects. 


\section{Comparison with other performance indicators}

The last decade has seen considerable research into the development and implementation of performance indicators, for many different types of construction work. For example, the emphasis on Total Quality Management has led to Benchmarking (Anderson and Pettersen 1996) and this in turn has had an impact on the development of Key Performance Indicators (KPIs). In the UK these initiatives were to a significant extent a direct response to both the Latham (Latham, 1994) and Egan Reports (Eagan, 1998). In 1999, the UK Department of Trade and Industry launched its first set of KPIs and these in turn have been developed for different sectors of the construction industry, for example, New Build Social Housing, New Build Private Housing, Major Infrastructure Projects and so on (DETR 2000).

These KPIs were then followed by indicators for different disciplines e.g. consultants and mechanical and electrical contractors, and in 2001, by indicators aimed specifically at design. Further details of these KPIs may be observed on the Construction Best Practice Programme website (CBPP, 2002).

A review of the list of performance indicators developed for micro-projects shows that they reflect the general indicators described above. This indicates that for microprojects the basic parameters for project performance and traditional benefits of performance monitoring i.e. the focus on the time, cost and quality of the work under consideration, remain the same as for larger projects. The major difference between existing indicators and those developed for micro-projects is the potential to identify improvements in the socio-economic impacts in keeping with a broader understanding of urban poverty. This is particularly true for community partnered projects. 
Over the past decades technology and resource based development theories concentrating on technology transfer have been replaced by those advocating the use of appropriate technology with community participation (Chambers 1987, Cohen and Uphoff 1980, Gopal, G. 1995, Narayan, D. 1995). These new paradigms take a people orientated approach and involve the intended beneficiaries in the planning and implementation of projects. This is particularly apparent in micro-projects. Of the 800 micro-projects on which the performance indicators were tested over half were community partnered projects where community groups were involved as either Promoter, Engineer or Contractor. The roles of these community groups ranged from informal (without having a legal contract) advisors to formally appointed microcontractors with legally binding contracts to construct the works, for which they receive cash payment. Further details of community partnered projects can be found in Sohail, (1997), Sohail and Baldwin, (2001), Sohail, (1999), Sohail and Cotton, (2000).

It was therefore necessary to provide performance indicators that reflected community involvement in micro-projects. These indicators included factors such as: the community involvement in the decision making process; the number of formal meetings; the number of informal meetings; the number of community labour days and the number of days training.

The performance indicators developed in this research comprise three groups: General Performance Indicators; Inter-Organisational, Co-operation and Partnership Indicators; and Socio-economic Indicators. These three groupings and the respective indicators that they embrace are detailed in Appendix II. The left-hand column of the tables lists the indicators by descriptive name. The right-hand column provides the 
basis on which these indicators were developed, the key sources of information required for performance measurement, an outline of how the parameters should be used together with additional comments and notes.

\section{Using the micro-project performance indicators}

67 indicators have been produced and used on micro-projects. Not all of the indicators are used on every project and it is not anticipated that all indicators need to be applied simultaneously, on future projects. Where the community initiates and/ or approves the proposed works, or where the community has a role in the procurement process itself, then the full range of performance indicators should be considered. Where this community aspect is not a factor, then a conventional contract and a subset of the indicators should be adopted.

The use of the indicators is, in most cases straightforward, with the need to collate information on events, monitor trends, and track changes in responsibility and control. The Tables describe for each indicator those data to be collected and the source of these data. In practice it has been found that data collection is best achieved through a worksheet. The use of a spreadsheet is desirable (though not essential) to speed up data management and analysis. Where a formal management information system exists, data relating to a large number of contracts can easily be handled by a Junior Engineer or equivalent level technician. Failing that, another option is to have a summary of indicators for each project updated regularly by a Junior Engineer or equivalent technician and filed in each contract or project file. The idea is neither to make performance monitoring a burden on the professionals involved in the day to day project management nor to make the cost of data collection either prohibitively 
high or uneconomic. There is scope for the indicators to be further subdivided and developed. As with any management information system there are resource implications to be considered if more detailed information is required. Another important issue is the magnitude and management of the information (e.g. both primary and output data). In the context of infrastructure projects in developing countries resources will always be scarce and these considerations are therefore important. The target should be the minimum new information to allow effective managerial decision-making. Most of the information needed is likely to be generated during the project management process. The actual indicators used and the data collection methods adopted must reflect the overall programme of works.

Data collected on a single performance indicator cannot be considered in isolation from other indicators. Information portrayed by a single indicator needs to be considered in conjunction with a number of indicators. It may be necessary to combine quantitative data, say from general performance indicators, with qualitative data from indicators relating to the community. For example, one can have twenty community meetings but that does not mean that those meetings were useful for the community. The atmosphere, participation and impacts from such meetings should also be examined using other indicators.

The use of the indicator relating to the quality of the works demands particular examination.(See Appendix II - Quality Indicators) This indicator was the only indicator identified by consensus for monitoring the quality of the work. This would appear to be a straightforward indicator of quality but, on all the projects reviewed, 
there were no recorded instances of work being rejected on the grounds of poor quality. However, anecdotal evidence suggests that work undertaken by microcontractors is by no means free from faults; these faults simply go undetected, unreported, or have no action taken about them. This latter point implies collusion between the supervising authority and the contractor. Quality of work is the central issue for service users and one way forward is to try to ensure greater independence in monitoring. There are two useful methods of doing this: first, to involve the user groups more closely in the monitoring of micro-projects, which requires both basic training and agreement at the outset between all parties (client, contractor, engineer and users) as to the accepted quality of work; secondly, the user group engages its own independent engineer or technician to oversee and approve the work.

The following general points also need to be kept in mind when using performance indicators: performance indicators should be truly representative of the quantities and characteristics that they are intended to represent; they should be verifiable, in other words, it should be possible to check that the values of the data or indicators presented are accurately reported; they should provide information that can be used by decisionmakers; the information must be available in time to influence decisions and their use should be linked into systems that allow feedback of information into the decision-making process. Clear rules of measurement are needed particularly if the performance measures are to be put to full use in the benchmarking life-cycle. The following section describes two instances of the use of the indicators.

\section{Examples of the use of the indicators.}

Two brief examples of the use of the indicators are now provided. The first example considers the two general indicators (termed R1 and R2) which monitor time and cost, 
the second considers community labour days on projects. The data provided is taken from a number of micro-projects which are listed in Table 1. (All of these projects were community partnered projects.)

The mean values of indicators R1 and R2 are presented in Table 2. Analysis of the performance data shows that, when reviewing the indicator R1 (Final Cost/Initial Contract Cost) obtained for the community partnered contracts awarded by SKAA, the final contract cost was, on average, only 0.67 times the initial cost (equivalent to a cost saving of 33\% against the estimate). Analysis of the individual data showed that project costs had been consistently over estimated. From the data available and the supporting documentation it was not clear why this was the situation. (In such instances further investigation is needed with the respective managers.) This represents one area where future improvements can be made. It should not of course be automatically assumed that this level of performance is beneficial. Whilst it represents a saving, there is a downside. Original budgets may not be fully spent, construction may be delayed. This is evident when factor R2 is examined for the SKAA contracts. Analysis of indicator R2 (Final Contract Duration/Initial Contract Duration) shows the average time growth on the same projects was 1.43 , which can be interpreted as a $43 \%$ increase in the duration of the works compared to the initial contract duration. On the projects managed by SKAA was there consistent underspend at the cost of a delay in delivery. Why? This shows the type of analysis needed across the indicators to arrive at a final view of the performance on the project(s).

Table 3 shows the performance indicated with respect to the community labour days for the different project groups. These are provided as examples of indicators from Part C, the Socio-Economic indicators. These indicators allow an estimate of the financial benefit to the community and the circulation of money in the local economy. 
Separate factors are used for male and female workers. For example, based on the situation reported:

- 300 unskilled labour days @ \$2 per day=\$600

- 40 skilled labour days @ \$5 per day = \$200

- materials purchased locally @ 40\% of contract sum (say \$5000)=\$2000

This results in an additional \$2800 circulating within the local economy.

These two examples show how the indicators may be used retrospectively to analyse performance across a range of projects. This analysis may then be used to influence either procurement practice or project monitoring and control. Obviously, if used on live projects, there is an opportunity to change current practice to bring about improvements.

In these two examples the rules for measurement of the indicators are clear, both in terms of what is to be measured and when. For some of the indicators the rules for measurement are not so straightforward and care has to be taken when comparing data across projects. This is an aspect of the use of the performance indicators that needs to be further developed before they may all be incorporated within a full benchmarking system.

The indicators are primarily concerned with performance at the level of the individual contract. However, it is important to recognise that, when brought together and analysed, the information obtained through such indicators can be important in shaping much broader issues such as programmes and policies. For instance, indicators of local employment resulting from specific schemes featuring communitypartnered procurement might provide a strong rationale for the development of changes in policy to encourage such partnerships. A related point is that while 
individual schemes may result in improvements in the local situation, assessment of the cumulative effect of a number of projects is necessary if overall impacts of different approaches to infrastructure provision are to be assessed.

\section{Conclusions and areas for future work}

This research has established 69 performance indicators for use on 'micro-projects' in developing countries. These indicators cover infrastructure works that are procured by either traditional methods of procurement or community partnering schemes. They have been developed by research involving not only professional experts but other stakeholders including the community end-users. The final list of indicators represents a set of measurements from which procurement teams and managers can select the appropriate basis to monitor either individual micro-projects or groups of projects within an overall programme. They therefore make an important contribution to the management of micro-projects in developing countries.

The actual indicators used for individual micro-projects will depend upon the overall programme of works, the procurement method and the local situation. Not all the indicators need be used on every project. Conversely, on some projects users may decide to add additional indicators to meet specific project needs. The use of the indicators must not however become a burden on the professionals involved or the cost of monitoring become prohibitively high or uneconomic.

The indicators do not represent a fully established 'benchmarking system' that can be simply adopted across micro-projects in different programmes or different countries. They include both quantitative and qualitative indicators and it may be necessary to combine quantitative data, say from general performance indicators, with qualitative data from indicators relating to the community. This aspect of combining quantitative 
and qualitative information on 'micro-projects' in developing countries and whether a subset of the indicators with the appropriate clear rules for measurement can be combined to form such a benchmarking system are areas for future research. Other opportunities for research include the assessment of how the indicators may be used to assess the overall performance of funding programmes . 


\section{REFERENCES}

1. Anderson, B. \& Pettersen, P. (1996) The Benchmarking Handbook, Chapman \& Hall, UK.

2. Chambers, R. (1997) Whose Reality Counts; Putting the first last, Intermediate Technology Publications, London.

3. Cohen, J.M. \& Uphoff, N.T. (1980) Participation's place in rural development: seeking clarity through specificity, World Development, 8(3), 218-235.

4. Construction Best Practice Programme (CBPP) (2002)

5. http://www.cbpp.org.uk

6. Department of the Environment, Transport and the Regions (2000) KPI Report for the Minister for Construction by the KPI working group dated January 2000, DETR, UK.

7. Eagan, J.L. (1998) Rethinking construction: The report of the Construction Task Force, Department of the Environment, Transport and the Regions, UK.

8. Gopal, G. (1995) Procurement and Disbursement Manual for Projects with Community Participation, World Bank Discussion Papers.312, The World Bank, Washington, DC.

9. Latham, M. (1994) Constructing the Team: Joint review of procurement and contractual arrangements in the United Kingdom Construction industry-Final Report, HMSO, London.

10. Narayan, D. (1995) The Contribution of People's Participation: Evidence from 121 water supply projects, Environmentally Sustainable Development Occasional Paper Series No. 1, The World Bank, Washington, DC.

11. Sohail, M. \& Cotton, A.(2000) Performance Monitoring of Micro-contracts for the Procurement of Urban Infrastructure, WEDC, Loughborough University.

12. Sohail, M. (1997) An investigation into the procurement of urban infrastructure in developing countries, $\mathrm{PhD}$ thesis, Loughborough University.

13. Sohail, M. and Baldwin, A.N. (2001) Partnering with the community - an option for infrastructure procurement, Proceedings of the Institution of Civil Engineers Municipal Engineer, 1454, .293-297.

14. Sohail, M. (1999) Community Partnered Procurement - Community Contracting Sustainable Lusaka Programme, 52 pp, United Nations/International Labour Office.

15. Sohail, M., Miles, D.W.J and Cotton, A.P. (2002) Developing monitoring indicators for urban micro contract in South Asia, Journal of International Project Management, 20(8), 583-591

16. United Nations Centre for Human Settlements (1987) Global Report on Human Settlements-1986, Oxford University Press, Oxford.

17. United Nations Centre for Human Settlements (1996) An Urbanizing World Global Report on Human Settlements 1996, Oxford University Press, Oxford.

18. United Nations Centre for Human Settlements (2001) Cities in a Globalizing World: Global Report on Human Settlements 2001, Earthscan publications, London.

19. World Bank (2000) Entering the $21^{\text {st }}$ Century, World Development Report 1999/2000, Oxford University Press, Oxford. 
Table 1. Number of contracts used for development and testing of the indicators

\begin{tabular}{|l|l|c|c|}
\hline Organizational context & Country & $\begin{array}{l}\text { No. of Non- } \\
\text { Community } \\
\text { contracts }\end{array}$ & $\begin{array}{l}\text { No. of } \\
\text { Community } \\
\text { contracts }\end{array}$ \\
\hline $\begin{array}{l}\text { Poverty related projects } \\
\text { (Project Management unit } \\
\text { and city level Authority) } \\
\text { (SIP) }\end{array}$ & India & 39 & 11 \\
\hline $\begin{array}{l}\text { Colombo Municipal } \\
\text { Corporation (Drainage and } \\
\text { project division) (City } \\
\text { Authority) (CMC) }\end{array}$ & Sri Lanka & 85 & nil \\
\hline $\begin{array}{l}\text { National Housing and } \\
\text { Development Authority } \\
\text { (NHDA) }\end{array}$ & Sri Lanka & nil & 59 \\
\hline $\begin{array}{l}\text { Clean Settlement Project } \\
\text { Unit (CSPU) }\end{array}$ & Sri Lanka & nil & 11 \\
\hline $\begin{array}{l}\text { Faisalabad Development } \\
\text { Authority /Water and } \\
\text { Sanitation Agency (City } \\
\text { Authority and project } \\
\text { Management unit) (FDA) }\end{array}$ & Pakistan & 98 & 71 \\
\hline $\begin{array}{l}\text { Karachi Municipal } \\
\text { Corporation and Karachi } \\
\text { Development Authority (City } \\
\text { Authority) (KMC/KDA) }\end{array}$ & Pakistan & nil & 56 \\
\hline $\begin{array}{l}\text { Sindh Katchi Abadi } \\
\text { Authority (Provincial } \\
\text { Authority) (SKAA) }\end{array}$ & Pakistan & nil & \\
\hline $\begin{array}{l}\text { Orangi Pilot Project (NGO) } \\
\text { (OPP) }\end{array}$ & Pakistan & & 564 \\
\hline $\begin{array}{l}\text { Anjuman-e Samaji-Behbood } \\
\text { (CBO) (ASB) }\end{array}$ & Pakistan & & \\
\hline Total & & & \\
\hline
\end{tabular}


Table 2. Inter-group comparison of the average value of the indicators for community contracts

\begin{tabular}{|l|l|l|l|l|l|l|l|l|}
\hline Items & SKAA & FDA & $\begin{array}{l}\text { KMC/ } \\
\text { KDA }\end{array}$ & OPP & NHDA & SIP & CSPU & ASB \\
\hline R1 & 0.67 & 0.97 & N/A & 1.08 & 1.15 & 0.92 & 0.86 & 1.12 \\
\hline R2 & 1.43 & 0.77 & N/A & 1.59 & 2.10 & 1.66 & 1.31 & N/A \\
\hline
\end{tabular}

Table 3. Community labour days per contract

\begin{tabular}{|l|l|l|l|l|l|}
\hline Contexts & Maximum & Minimum & Range & Mean & Mode \\
\hline SKAA Male unskilled & 575 & 20 & 555 & 202 & 20 \\
\hline SKAA Male skilled & 70 & 42 & 28 & 56 & 42 \\
\hline $\begin{array}{l}\text { NHDA Male } \\
\text { unskilled }\end{array}$ & 40 & 15 & 25 & 26.11 & 30 \\
\hline $\begin{array}{l}\text { NHDA Female } \\
\text { unskilled }\end{array}$ & 45 & 20 & 25 & 35.28 & 40 \\
\hline NHDA Male skilled & 25 & 10 & 15 & 20.28 & 20 \\
\hline $\begin{array}{l}\text { NHDA-Female } \\
\text { unskilled }\end{array}$ & 50 & 20 & 30 & 29.17 & 30 \\
\hline SIP Male unskilled & 500 & 115 & 385 & 299.75 & 115 \\
\hline SIP Female unskilled & 300 & 85 & 215 & 165.75 & 85 \\
\hline SIP Male skilled & 100 & 4 & 96 & 47.25 & 4 \\
\hline SIP Female skilled & nil & nil & nil & nil & nil \\
\hline CSPU Male unskilled & 50 & 10 & 40 & 24.55 & 20 \\
\hline $\begin{array}{l}\text { CSPU Female } \\
\text { unskilled }\end{array}$ & 75 & 15 & 60 & 35.91 & 30 \\
\hline CSPU Male skilled & 30 & 10 & 20 & 18.18 & 20 \\
\hline CSPU Female skilled & 50 & 10 & 40 & 28.18 & 20 \\
\hline
\end{tabular}




\section{APPENDIX I}

\section{Examples of questions and the format used in the data collection}

The following sample questions are examples of those asked in the one-to-one interviews.

Sample questions from the semi-structured interviews. All responses were recorded for further analysis.

Please confirm the type of contractor involved. If this included the community how were the community groups formed?

What documentation was involved? Were there any written contracts? Any standard conditions of contract? Was the contract verbal?

Who decided that the work was complete? Was the community involved? Was there any documentation?

Did any disputes arise? At what stages? Whom were the disputes between and how were they resolved?

How many formal community meetings were held? Which different groups attended the meetings? ( men, women, owners, renters, community leaders?

Group discussion to capture the wider impacts relating to the provision of urban infrastructure and services. Typical questions:

Are the people satisfied after the implementation of this facility?

Has the facility improved access? How?

Has the facility contributed towards more improved community relationships and decreased the conflict between community members?

Are the people more convinced as to the participatory approach of the project?

Are people , after implementing this project, taking local initiatives? Give examples

\section{Example of the format for a two day workshop held to discuss community partnered projects}

Day 1: introduction; objectives of the workshop; conventional procurement procedures; roles, objectives and micro-projects in urban infrastructure and services; conventional and community based micro-contractors; community initiatives-case studies; discussion of the case studies.

Day 2: barriers to the assimilation of the initiatives in the Government Sector; How the barriers were overcome; attitudes of the stakeholders; associated costs and benefits of community partnered procurement; changes and training required; actions required to advance new concepts. 
APPENDIX II

\section{General performance indicators for monitoring of micro-contracts}

\section{General Indicators}

\begin{tabular}{|c|c|}
\hline Indicator & Description \\
\hline $\begin{array}{l}\text { Handing/ taking over } \\
\text { process: formal taking over } \\
\text { by Maintenance agencies, } \\
\text { defect liability period. }\end{array}$ & $\begin{array}{l}\text { 20. Why use this indicator? To monitor who owns the infrastructure, the roles } \\
\text { and responsibilities and the time period involved. } \\
\text { 21. Key sources of information: contract document, files, and handing/taking } \\
\text { over documents. } \\
\text { 22. How to determine the indicator: review the documents, identify who does } \\
\text { what. Note the date of completion, the end of defect liability period and the } \\
\text { date when the assets were formally/informally taken over. }\end{array}$ \\
\hline $\begin{array}{l}\text { Was the community } \\
\text { involved in the Operation } \\
\text { \& Maintenance of the } \\
\text { infrastructure? }\end{array}$ & $\begin{array}{l}\text { 1. Why use this indicator? To monitor the involvement of the community in } \\
\text { operation and maintenance which is a manifestation of the ownership of the } \\
\text { project and the ongoing care of the works. } \\
\text { 2. Key sources of information: interviews with key informants, observation } \\
\text { and condition surveys of the assets. } \\
\text { 3. How to determine the indicator : formal/informal interviews and a review of } \\
\text { the documents. }\end{array}$ \\
\hline Number of disputes. & $\begin{array}{l}\text { 1. Why use this indicator? Because the number of disputes indicates the } \\
\text { general working environment, the power relationships and the methods of } \\
\text { conflict resolution. } \\
\text { 2. Key sources of information: the contract files and interviews with key } \\
\text { informants. } \\
\text { 3. How to determine the indicator : formal/informal interviews and a review } \\
\text { of the documents }\end{array}$ \\
\hline $\begin{array}{l}\text { Incidences of the imposition } \\
\text { of penalties/damages. }\end{array}$ & $\begin{array}{l}\text { 1. Why use this indicator? Because the imposition of penalties/damages } \\
\text { indicates fundamental failures in performance and the power relations } \\
\text { 2. Key sources of information: the contract files and interviews with key } \\
\text { informants. } \\
\text { 3. How to determine the indicator : formal/informal interviews and a review } \\
\text { of the documents. }\end{array}$ \\
\hline $\begin{array}{l}\text { Incidences of deviations in } \\
\text { work requirements and the } \\
\text { reasons for these. }\end{array}$ & $\begin{array}{l}\text { 1. Why use this indicator? Because the changes in work requirements reflect } \\
\text { the quality of the initial brief, the attitude of the contractors and the changing } \\
\text { circumstances. } \\
\text { 2. Key sources of information: from the contract files. } \\
\text { 3. How to determine the indicator: make a review of the documents. }\end{array}$ \\
\hline $\begin{array}{l}\text { Incidences of delay in the } \\
\text { supply of materials, tools } \\
\text { and plant }\end{array}$ & $\begin{array}{l}\text { 1. Why use this indicator? To assess the department of work's supply } \\
\text { performance on departmental works and labour contracts. } \\
\text { 2. Key sources of information: site records and site supervisors. } \\
\text { 3. How to determine the indicator: from formal/informal interviews and a } \\
\text { review of the documents. }\end{array}$ \\
\hline
\end{tabular}




\section{Time Indicators}

\begin{tabular}{|c|c|}
\hline Indicator & Description \\
\hline $\begin{array}{l}\text { Incidences of applications } \\
\text { for extra time and reasons } \\
\text { for these applications. }\end{array}$ & $\begin{array}{l}\text { 1. Why use this indicator? To assess the risks of time overruns and their } \\
\text { reasons and to understand the factors affecting time performance } \\
\text { 2. Key sources of information: the contract files and management reports. } \\
\text { 3. How to determine the indicator: review of the documents and log the } \\
\text { incidences. }\end{array}$ \\
\hline $\begin{array}{l}\text { Time growth } \\
\text { (Final contract duration / } \\
\text { Initial contract duration) }\end{array}$ & $\begin{array}{l}\text { 1. Why use this indicator? To identify the overall control of the time schedule } \\
\text { 2. Key sources of information: contract files and key informants. } \\
\text { 3. How to determine the indicator: determine the initial and final contract } \\
\text { duration. Divide the final contract duration by the initial contract duration. }\end{array}$ \\
\hline $\begin{array}{l}\text { Lead time } \\
\text { (Time required to reach the } \\
\text { stage of commencement of } \\
\text { works or services / contract } \\
\text { duration.) }\end{array}$ & $\begin{array}{l}\text { 1. Why use this indicator? The lead time is important in the overall delivery } \\
\text { time of the infrastructure. This indicator along with the time lags indicates the } \\
\text { performance of the procurement process and promoter efficiency in } \\
\text { contracting out the work. } \\
\text { 2. Key sources of information: the project file and key informants. } \\
\text { 3. How to determine the indicator: determine the time lag between the } \\
\text { establishment of need and the contract commencement. Divide that time lag } \\
\text { by the contract period. The units in which the duration is measured should be } \\
\text { consistent. }\end{array}$ \\
\hline $\begin{array}{l}\text { Time taken from approval } \\
\text { stage to reach the tender } \\
\text { inviting stage or equivalent } \\
\text { stage. }\end{array}$ & $\begin{array}{l}\text { 1. Why use this indicator? This indicator reflects the time performance of the } \\
\text { promoter in reaching the stage of tender invitation. This is important for the } \\
\text { overall delivery time of the infrastructure. } \\
\text { 2. Key sources of information: project files and key informants. } \\
\text { 3. How to determine the indicator: determine the dates for approvals and } \\
\text { invitation to tenders. Determine the difference between the dates. }\end{array}$ \\
\hline $\begin{array}{l}\text { Time taken from approval } \\
\text { to contract stage }\end{array}$ & $\begin{array}{l}\text { 1. Why use this indicator? This is an indicator of the time performance of the } \\
\text { Promoter in the procurement process. The indicator reflects the time } \\
\text { performance of the procurement process prior to the start of contract. The } \\
\text { time taken to reach the contract stage is an important factor in overall delivery } \\
\text { time of the infrastructure } \\
\text { 2. Key sources of information: project files and key informants. } \\
\text { 3. How to determine the indicator: determine the dates for approvals and } \\
\text { contract start. Determine the difference between the dates. }\end{array}$ \\
\hline $\begin{array}{l}\text { Time taken between tender } \\
\text { opening and tender } \\
\text { approval }\end{array}$ & $\begin{array}{l}\text { 1. Why use this indicator? This is an indicator of the time performance of the } \\
\text { Promoter in the procurement process. The pre-contract procurement process } \\
\text { is divided into different stages. The overall delivery time of urban } \\
\text { infrastructure is dependent on the performance of each element. This indicates } \\
\text { the time performance of one such element. } \\
\text { 2. Key sources of information: project files. } \\
\text { 3. How to determine the indicator: determine the dates for tender opening and } \\
\text { approval. Calculate the difference. }\end{array}$ \\
\hline
\end{tabular}




\begin{tabular}{|c|c|}
\hline $\begin{array}{l}\text { Time taken between tender } \\
\text { invitation and start of } \\
\text { contract }\end{array}$ & $\begin{array}{l}\text { 1. Why use this indicator? This is an indicator of the time performance of the } \\
\text { Promoter in the procurement process. The pre-contract procurement process } \\
\text { is divided into different stages. The overall delivery time of urban } \\
\text { infrastructure is dependent on the performance of each element. This indicates } \\
\text { the time performance of one such element. } \\
\text { 2. Key sources of information: project files, tender documents and key } \\
\text { informants. } \\
\text { 3. How to determine the indicator: determine the dates for tender invitation } \\
\text { and contract commencement. Calculate the difference }\end{array}$ \\
\hline $\begin{array}{l}\text { Time lag between tender } \\
\text { opening and technical } \\
\text { sanction }\end{array}$ & $\begin{array}{l}\text { 1. Why use this indicator? This is an indicator of the time performance of the } \\
\text { Promoter in the procurement process. The pre-contract procurement process } \\
\text { is divided into different stages. The overall delivery time of urban } \\
\text { infrastructure is dependent on the performance of each element. This indicates } \\
\text { the time performance of one such element. } \\
\text { 2. Key sources of information: project files, tender documents. } \\
\text { 3. How to determine the indicator: determine the date for tender opening and } \\
\text { the date for technical sanction. Calculate the difference. }\end{array}$ \\
\hline $\begin{array}{l}\text { Time lag between the actual } \\
\text { completion and the } \\
\text { technical sanction }\end{array}$ & $\begin{array}{l}\text { 1. Why use this indicator? This is an indicator of the time performance of the } \\
\text { Promoter in the procurement process. The pre-contract procurement process } \\
\text { is divided into different stages. The overall delivery time of urban } \\
\text { infrastructure is dependent on the performance of each element. This indicates } \\
\text { the time performance of one such element. } \\
\text { 2. Key sources of information: project files, contract documents and key } \\
\text { informants. } \\
\text { 3. How to determine the indicator: determine the dates for actual completion } \\
\text { and technical sanction. Calculate the difference. }\end{array}$ \\
\hline $\begin{array}{l}\text { Time lag between tender } \\
\text { opening and Notice Inviting } \\
\text { Tenders }\end{array}$ & $\begin{array}{l}\text { 1. Why use this indicator? This is indicator of the time performance of the } \\
\text { Promoter in the procurement process. The pre-contract procurement process } \\
\text { is divided into different stages. The overall delivery time of urban } \\
\text { infrastructure is dependent on the performance of each element. This indicates } \\
\text { the time performance of one such element. } \\
\text { 2. Key sources of information: project files, tender documents and key } \\
\text { informants. } \\
\text { 3. How to determine the indicator: determine the dates for tender opening and } \\
\text { tender invitation. Calculate the difference. }\end{array}$ \\
\hline $\begin{array}{l}\text { Time taken between the } \\
\text { contract start date and the } \\
\text { actual start at site }\end{array}$ & $\begin{array}{l}\text { 1. Why use this indicator? The time lag between the work order and the actual } \\
\text { start reflect the mobilisation capacity of the contractor. } \\
\text { 2. Key sources of information: contract files and key informants. } \\
\text { 3. How to determine the indicator: determine the contract start date and the } \\
\text { physical start at site. Calculate the difference between those dates. }\end{array}$ \\
\hline $\begin{array}{l}\text { Time taken to start } \\
\text { operation and maintenance } \\
\text { after the contract is } \\
\text { completed }\end{array}$ & $\begin{array}{l}\text { 1. Why use this indicator? The time taken to start the operation and } \\
\text { maintenance reflects the efficiency in ensuring the ongoing sustainability of } \\
\text { the infrastructure. and maintenance - the urban infrastructure may not be as } \\
\text { sustainable. } \\
\text { 2. Key sources of information: contract documents, project files, handing and } \\
\text { taking over documents and key informants. } \\
\text { 3. How to determine the indicator: determine the contract completion date and } \\
\text { the date for taking over by the concerned agencies. In the case of informal and } \\
\text { community contracts equivalent dates need to be determined. Calculate the } \\
\text { difference between those dates. }\end{array}$ \\
\hline
\end{tabular}




\section{Cost Indicators}

\begin{tabular}{|c|c|}
\hline Indicator & Description \\
\hline $\begin{array}{l}\text { Cost growth } \\
\text { (Final contract cost /Initial } \\
\text { contract cost.) }\end{array}$ & $\begin{array}{l}\text { 1. Why use this indicator? The basic performance of cost control. } \\
\text { 2. Key sources of information: contract files and key informants. } \\
\text { 3. How to determine the indicator: identify the initial costs at the start of } \\
\text { contract and the costs at the time of completion; divide the total completion } \\
\text { cost by the total initial cost } \\
\text { 4. Comments: the ratio reflects the cost control used in the project. There may } \\
\text { be many reasons for the high or low cost growth, for example political } \\
\text { situation, inflation, climate - but here we are focusing on the magnitude and } \\
\text { not the reason. }\end{array}$ \\
\hline $\begin{array}{l}\text { Accuracy of preliminary } \\
\text { technical estimates } \\
\text { (Technical sanction } \\
\text { cost/Engineer’s detailed } \\
\text { estimate.) }\end{array}$ & $\begin{array}{l}\text { 1. Why use this indicator? To assess the accuracy of the cost estimate. The } \\
\text { preliminary estimate is important as this dictates the approved cost of the } \\
\text { project. } \\
\text { 2. Key sources of information: contract files and key informants. } \\
\text { 3. How to determine the indicator: determine the preliminary estimates and } \\
\text { detailed Engineer's estimates. Divide the preliminary estimates by the detailed } \\
\text { estimates. }\end{array}$ \\
\hline $\begin{array}{l}\text { Proximity of Engineer's } \\
\text { estimated cost and the } \\
\text { initial contract cost } \\
\text { (Engineer's detailed estimated } \\
\text { cost /contract initial cost.) }\end{array}$ & $\begin{array}{l}\text { 1. Why use this indicator? This indicator monitors the accuracy of the } \\
\text { Engineer's estimates and the contract initial cost. The ratio reveals how close } \\
\text { or otherwise the estimate is to the initial contract price. } \\
\text { Key sources of information: tender document, project files and contract } \\
\text { document. In the case of verbal or informal contracts equivalent information } \\
\text { may be found from the key informants. } \\
\text { 3. How to determine the indicator: determine the Engineer's estimated cost } \\
\text { and the initial contract cost. Divide the Engineer's estimated cost by the initial } \\
\text { contract cost. }\end{array}$ \\
\hline $\begin{array}{l}\text { Proximity of Engineer's } \\
\text { estimated cost and the final } \\
\text { contract cost } \\
\text { (Detailed estimated cost / } \\
\text { completion cost.) }\end{array}$ & $\begin{array}{l}\text { 1. Why use this indicator? The ratio reflects the accuracy of the Engineer's } \\
\text { estimated cost to the cost of completion. This complements the idea of cost } \\
\text { growth ratio above. } \\
\text { 2. Key sources of information: tender document, project files and contract } \\
\text { document. In the case of verbal or informal contracts equivalent information } \\
\text { may be found from the key informants. } \\
\text { 3. How to determine the indicator: determine the Engineer's estimate and the } \\
\text { final contract cost. Divide the estimated cost by the final contract cost. }\end{array}$ \\
\hline
\end{tabular}

\section{Quality Indicators}

\begin{tabular}{|l|l|}
\hline Indicator & Description \\
\hline $\begin{array}{l}\text { Incidences when the work } \\
\text { was rejected. }\end{array}$ & $\begin{array}{ll}\text { Why use this indicator? Incidences of rejection indicate the quality control } \\
\text { mechanism and power. } \\
\text { Key sources of information: site records, contract file, project memos and } \\
\text { key site supervisors. }\end{array}$ \\
\hline How to determine the indicator: review of the documents and interviews.
\end{tabular}




\section{Indicators for Inter-organisational co-operation and partnership}

\begin{tabular}{|c|c|}
\hline Indicators & Description \\
\hline $\begin{array}{l}\text { The documentation involved } \\
\text { ( Were there any written contracts? Any standard } \\
\text { conditions of contact? Was the contract verbal ?) }\end{array}$ & $\begin{array}{l}\text { 1. Why use this indicator? To identify the degree of } \\
\text { formality adopted and the modes of communication } \\
\text { together with the implications of community access to the } \\
\text { project. } \\
\text { 2. Key sources of information: the contract documents and } \\
\text { key informants. } \\
\text { 3. How to determine the indicator: review contract } \\
\text { documents and consult key informants. }\end{array}$ \\
\hline $\begin{array}{l}\text { How the works commenced, any ceremonies } \\
\text { etc. }\end{array}$ & $\begin{array}{l}\text { 1. Why use this indicator? To identify the perceived } \\
\text { importance of the work by the community. } \\
\text { 2. Key sources of information: key informant and } \\
\text { observation if the work is about to commence. } \\
\text { 3. How to determine the indicator: talking and observing. }\end{array}$ \\
\hline $\begin{array}{l}\text { Community involvement in the decision } \\
\text { making process: } \\
\text { Who were involved in deciding that the work } \\
\text { was complete? } \\
\text { Who were involved in determining the cost? } \\
\text { What was the satisfaction of the community? }\end{array}$ & $\begin{array}{l}\text { 1. Why use this indicator? To assess community power and } \\
\text { authority in the decision making process. } \\
\text { 2. Key sources of information: project notes, observation } \\
\text { of community interactions, records of community } \\
\text { participation in the different stages of decision making, } \\
\text { key informants. } \\
\text { 3. How to determine the indicator: review contract } \\
\text { documents and consult key informants }\end{array}$ \\
\hline $\begin{array}{l}\text { Identify the number of formal community } \\
\text { meetings during; planning and design, } \\
\text { implementation and post completion. Also } \\
\text { identify the different groups that attended the } \\
\text { meetings such as men, women, owners, } \\
\text { renters, community leaders etc. }\end{array}$ & $\begin{array}{l}\text { 1. Why use this indicator? This will indicate the formal } \\
\text { interaction from different parts of the community. } \\
\text { 2. Key sources of information: key informants and project } \\
\text { files. } \\
\text { 3. How to determine the indicator: determine the number } \\
\text { of formal meetings at different stages of the contract and } \\
\text { the participants. }\end{array}$ \\
\hline
\end{tabular}

Number of informal community meetings during; planning and design, implementation and post completion. Also mention the different groups that attended the meetings such as men, women, owners, renters, community leaders etc.
1. Why use this indicator? This will indicate the informal interaction from different parts of the community.

2. Key sources of information: key informants and project files.

3. How to determine the indicator: determine the number of informal meetings at different stages of the contract.

1. Why use this indicator? To monitor the level of interaction, transparency and information sharing between the stakeholders.

Score the interaction between the officials and the community groups in meetings.

(This should include ; planning and design, implementation and post completion meetings)
2. Key sources of information: key informants and meeting notes, if any.

3. How to determine the indicator: interviews, observation at meetings and by review of meeting notes. Scale of 1-10 can be used, I indicating minimal level of interaction while 10 maximum. 


\begin{tabular}{|c|c|}
\hline $\begin{array}{l}\text { Score community attendance during; planning } \\
\text { and design, implementation and post } \\
\text { completion meetings }\end{array}$ & $\begin{array}{l}\text { 1. Why use this indicator? monitor the level of community } \\
\text { participation in the procurement process. } \\
\text { 2. Key sources of information: key informants, } \\
\text { observations and meeting minutes. } \\
\text { 3. How to determine the indicator: review of any } \\
\text { documents and interviews. Scale of } 1-10 \text { can be used, I } \\
\text { indicating minimal level while } 10 \text { maximum. }\end{array}$ \\
\hline $\begin{array}{l}\text { Identify the different groups that attended the } \\
\text { meetings such as men, women, owners, } \\
\text { renters, community leaders etc. during; } \\
\text { planning and design, implementation and post } \\
\text { completion. }\end{array}$ & $\begin{array}{l}\text { 1. Why use this indicator? monitor the level of } \\
\text { participation and access to knowledge and information. } \\
\text { 2. Key sources of information: key informants and meeting } \\
\text { minutes. } \\
\text { 3. How to determine the indicator: interviews and review } \\
\text { of meeting documentation. }\end{array}$ \\
\hline $\begin{array}{l}\text { Identify particular groups who did not attend } \\
\text { either formal or informal meetings during; } \\
\text { planning and design, implementation and post } \\
\text { completion. }\end{array}$ & $\begin{array}{l}\text { 1. Why use this indicator? identify disadvantaged groups. } \\
\text { 2. Key sources of information: key informants. } \\
\text { 3. How to determine the indicator: by interviews. }\end{array}$ \\
\hline $\begin{array}{l}\text { Score the level of participation during; } \\
\text { planning and design, implementation and post } \\
\text { completion by male attendees, female } \\
\text { attendees and members of specific groups }\end{array}$ & $\begin{array}{l}\text { 1. Why use this indicator? To assess the quality of the } \\
\text { community participation in the meetings. } \\
\text { 2. Key sources of information: key informants. } \\
\text { 3. How to determine the indicator: interviews. Scale of 1- } \\
10 \text { can be used, I indicating minimal level while } 10 \\
\text { maximum. }\end{array}$ \\
\hline $\begin{array}{l}\text { Score the atmosphere of the meetings during; } \\
\text { planning and design, implementation and post } \\
\text { completion. }\end{array}$ & $\begin{array}{l}\text { 1. Why use this indicator? To assess the quality of } \\
\text { community participation in the meetings. } \\
\text { 2. Key sources of information: key informants and minutes } \\
\text { of meetings. } \\
\text { 3. How to determine the indicator: interviews and review } \\
\text { of meeting documentation. Scale of } 1-10 \text { can be used, I } \\
\text { indicating minimal level of satisfaction while } 10 \\
\text { maximum. }\end{array}$ \\
\hline $\begin{array}{l}\text { Estimate the percentage of the time taken by } \\
\text { the community in discussing issues in planning } \\
\text { and design, implementation and post } \\
\text { completion meetings. }\end{array}$ & $\begin{array}{l}\text { 1. Why use this indicator? To assess the quality of } \\
\text { community meetings; what do they discuss, who discusses } \\
\text { and how. } \\
\text { 2. Key sources of information: key informants and minutes } \\
\text { of meetings. } \\
\text { 3. How to determine the indicator; interviews and review } \\
\text { of meeting documentation. }\end{array}$ \\
\hline $\begin{array}{l}\text { Identify the number of meetings with the } \\
\text { disadvantaged groups during the planning and } \\
\text { design, implementation and post completion } \\
\text { phases. ( The groups should be identified.) }\end{array}$ & $\begin{array}{l}\text { 1. Why use this indicator? To identify the access provided } \\
\text { to disadvantaged groups. } \\
\text { 2. Key sources of information: key informants and project } \\
\text { files. } \\
\text { 3. How to determine the indicator: interviews and review } \\
\text { of the documents. }\end{array}$ \\
\hline $\begin{array}{l}\text { The time taken for approvals from donors } \\
\text { during; planning and design, implementation } \\
\text { and post completion. }\end{array}$ & $\begin{array}{l}\text { 1. Why use this indicator? To monitor the efficiency of } \\
\text { donors in the procurement process. } \\
\text { 2. Key sources of information: project files. } \\
\text { 3. How to determine the indicator: determine the } \\
\text { difference between the dates when the project sent } \\
\text { documents for approval and when they were returned from }\end{array}$ \\
\hline
\end{tabular}


Performance indicators for micro-projects in developing countries

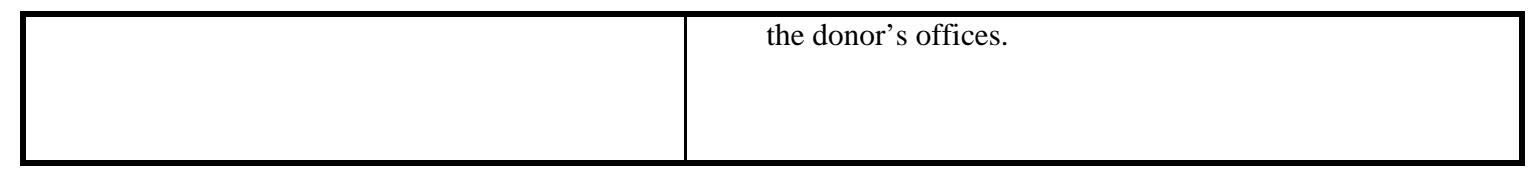




\begin{tabular}{|c|c|}
\hline $\begin{array}{l}\text { The time that elapses from the first } \\
\text { community meeting to the approval of works } \\
\text { for implementation and the parties involved in } \\
\text { the approval cycle. }\end{array}$ & $\begin{array}{l}\text { 1. Why use this indicator? this indicates the delivery time } \\
\text { as perceived by the community. } \\
\text { 2. Key sources of information: key informants and project } \\
\text { files. } \\
\text { 3. How to determine the indicator: interviews and review } \\
\text { of the documents. }\end{array}$ \\
\hline $\begin{array}{l}\text { Incidences of community interest in playing an } \\
\text { active role in the community partnered } \\
\text { procurement during the planning and design, } \\
\text { implementation and post completion phases. }\end{array}$ & $\begin{array}{l}\text { 1. Why use this indicator? To identify and monitor } \\
\text { community initiatives. } \\
\text { 2. Key sources of information: key informants and project } \\
\text { documentation. } \\
\text { 3. How to determine the indicator: interviews with project } \\
\text { and community representatives. }\end{array}$ \\
\hline $\begin{array}{l}\text { The number of works vetted by the } \\
\text { community and the representatives involved in } \\
\text { those meetings. }\end{array}$ & $\begin{array}{l}\text { 1. Why use this indicator? To identify community } \\
\text { participation in reviewing the works and services. } \\
\text { 2. Key sources of information: project files and key } \\
\text { informants. } \\
\text { 3. How to determine the indicator; interviews and review } \\
\text { of the documents. }\end{array}$ \\
\hline $\begin{array}{l}\text { Number of organisations or departments or } \\
\text { agencies involved. }\end{array}$ & $\begin{array}{l}\text { 1. Why use this indicator? To monitor the complexity of } \\
\text { organisational design. } \\
\text { 2. Key sources of information: project files and key } \\
\text { informants. } \\
\text { 3. How to determine the indicator: review of the } \\
\text { documents and interviews. }\end{array}$ \\
\hline $\begin{array}{l}\text { Community participation in meetings . Who } \\
\text { were involved in those meetings and their roles } \\
\text { in the planning and design, implementation } \\
\text { and post completion phases. }\end{array}$ & $\begin{array}{l}\text { 1. Why use this indicator? To identify community } \\
\text { participation in meetings. } \\
\text { 2. Key sources of information: project files and key } \\
\text { informants. } \\
\text { 3. How to use this indicator: review of the documents and } \\
\text { interviews. }\end{array}$ \\
\hline $\begin{array}{l}\text { Number of incidences of evaluation meetings } \\
\text { with the community. Who were involved in } \\
\text { those meetings? }\end{array}$ & $\begin{array}{l}\text { 1. Why use this indicator? To identify community } \\
\text { participation in the evaluation of projects. } \\
\text { 2. Key sources of information: project files and key } \\
\text { informants. } \\
\text { 3. How to determine the indicator: review of the } \\
\text { documents and interviews. }\end{array}$ \\
\hline $\begin{array}{l}\text { Score the potential for community } \\
\text { organisation around some other issue as a } \\
\text { result of the community partnered } \\
\text { procurement }\end{array}$ & $\begin{array}{l}\text { 1. Why use this indicator? To assess the indirect impact of } \\
\text { procurement on capacity building. } \\
\text { 2. Key sources of information: project information and key } \\
\text { informants. } \\
\text { 3. How to determine the indicator: review of the } \\
\text { documents and interviews. Scale of } 1-10 \text { can be used, I } \\
\text { indicating minimal level while } 10 \text { maximum. }\end{array}$ \\
\hline $\begin{array}{l}\text { Score the attitude of officials to co-operate at a } \\
\text { working level with other sections, departments } \\
\text { or organisations }\end{array}$ & $\begin{array}{l}\text { 1. Why use this indicator? To assess the indirect impact of } \\
\text { procurement on changes in attitudes of officials. } \\
\text { 2. Key sources of information: key informants and project } \\
\text { personnel. } \\
\text { 3. How to determine the indicator: interviews. Scale of 1- } \\
10 \text { can be used, I indicating minimal level while } 10 \\
\text { maximum. }\end{array}$ \\
\hline
\end{tabular}


\begin{tabular}{|l|l|}
\hline & \\
\hline
\end{tabular} 


\begin{tabular}{|l|l|}
\hline $\begin{array}{l}\text { Score the attitude of officials to co- } \\
\text { operate/partner with community }\end{array}$ & $\begin{array}{ll}\text { Why use this indicator? indirect impact of procurement } \\
\text { on changes in attitudes of officials } \\
\text { Key sources of information: key informants and project } \\
\text { officials. }\end{array}$ \\
\hline $\begin{array}{l}\text { How to determine the indicator: interviews. Scale of 1- } \\
10 \text { can be used, I indicating minimal level while } 10 \\
\text { maximum. }\end{array}$ \\
\hline
\end{tabular}

\section{Socio-economic issues (enterprise development, poverty alleviation and empowerment)}

\begin{tabular}{|c|c|}
\hline Indicators & Description \\
\hline $\begin{array}{l}\text { Number of community labour days (unskilled ). } \\
\text { - } \quad \text { Male } \\
\text { - } \quad \text { Female }\end{array}$ & $\begin{array}{l}\text { 1. Why use this indicator? To identify the indirect } \\
\text { financial benefit to the community. } \\
\text { 2. Key sources of information: project files and } \\
\text { key informants. } \\
\text { 3. How to determine the indicator: review of the } \\
\text { documents and interviews. }\end{array}$ \\
\hline $\begin{array}{l}\text { Number of community labour days (skilled ). } \\
\text { - } \quad \text { Male } \\
\text { - } \quad \text { Female }\end{array}$ & $\begin{array}{l}\text { 1. Why use this indicator? To identify the indirect } \\
\text { financial benefit to the community. } \\
\text { 2. Key sources of information: project files and } \\
\text { key informants. } \\
\text { 3. How to determine the indicator: review of the } \\
\text { documents and interviews. }\end{array}$ \\
\hline $\begin{array}{l}\text { The identity of the skilled and unskilled workers } \\
\text { involved in the community labour days. }\end{array}$ & $\begin{array}{l}\text { 1. Why use this indicator? To identify the access } \\
\text { of all the community to work. } \\
\text { 2. Key sources of information: project files and } \\
\text { key informants. } \\
\text { 3. How to determine the indicator: interviews } \\
\text { and review of the documents. }\end{array}$ \\
\hline $\begin{array}{l}\text { The number of formal and informal days training } \\
\text { provided in skills development related to } \\
\text { procurement of infrastructure. }\end{array}$ & $\begin{array}{l}\text { 1. Why use this indicator? To quantify the } \\
\text { training provided and mechanisms for training. } \\
\text { 2. Key sources of information: project files. } \\
\text { 3. How to determine the indicator: review of the } \\
\text { documents. }\end{array}$ \\
\hline The number of women trained & $\begin{array}{l}\text { 1. Why use this indicator? To quantify and } \\
\text { identify the skills development for women. } \\
\text { 2. Key sources of information: key informants } \\
\text { and project files. } \\
\text { 3. How to determine the indicator: interviews } \\
\text { and review of the documents. }\end{array}$ \\
\hline The organisation that provided the training? & $\begin{array}{l}\text { 1. Why use this indicator? To identify the } \\
\text { mechanisms of training provision. } \\
\text { 2. Key sources of information: key informants } \\
\text { and project files. } \\
\text { 3. How to determine the indicator: interviews } \\
\text { and review of the documents. }\end{array}$ \\
\hline
\end{tabular}




\begin{tabular}{|l|l|}
\hline & \\
\hline The persons who received the training ? & $1 . \quad \begin{array}{l}\text { Why use this indicator? to monitor } \\
\text { transparency in provision of training. }\end{array}$ \\
2. $\begin{array}{l}\text { Key sources of information: key informants } \\
\text { and project files. }\end{array}$ \\
3ow to determine the indicator: interviews \\
and review of the documents.
\end{tabular}

\begin{tabular}{|c|c|}
\hline $\begin{array}{l}\text { The nature of training } \\
\text { (For example 'on the job' or classroom.) }\end{array}$ & $\begin{array}{l}\text { 1. Why use this indicator? to monitor the nature } \\
\text { of frequently provided training. } \\
\text { 2. Key sources of information: key informants } \\
\text { and project files. } \\
\text { 3. How to determine the indicator: analysis of } \\
\text { the training documentation. }\end{array}$ \\
\hline $\begin{array}{l}\text { The formal qualifications achieved as a result of } \\
\text { the training? }\end{array}$ & $\begin{array}{l}\text { 1. Why use this indicator? To determine the level } \\
\text { of achievement of those trained } \\
\text { 2. Key sources of information: Education } \\
\text { department documents and key informants. } \\
\text { 3. How to determine the indicator: interviews } \\
\text { and review of the documents. }\end{array}$ \\
\hline Feedback on the training provided. & $\begin{array}{l}\text { 1. Why use this indicator? To enable the } \\
\text { development of future training programmes and } \\
\text { to identify training needs. } \\
\text { 2. Key sources of information: key informants - } \\
\text { trainees. } \\
\text { 3. How to determine the indicator: interviews } \\
\text { and formal feedback documentation. }\end{array}$ \\
\hline $\begin{array}{l}\text { Incidences of the training of others by those } \\
\text { trained }\end{array}$ & $\begin{array}{l}\text { 1. Why use this indicator? To identify the } \\
\text { secondary impacts of training within the } \\
\text { community. } \\
\text { 2. Key sources of information: project files and } \\
\text { key informants. } \\
\text { 3. How to determine the indicator: interviews } \\
\text { and review of available documentation. }\end{array}$ \\
\hline Incidences of acquired skills being used. & $\begin{array}{l}\text { 1. Why use this indicator? To identify use of } \\
\text { acquired skills. } \\
\text { 2. Key sources of information: project files and } \\
\text { key informants. } \\
\text { 3. How to determine the indicator: interviews } \\
\text { and review of the documents. }\end{array}$ \\
\hline $\begin{array}{l}\text { Evidence of the development of existing or new } \\
\text { enterprises due to infrastructure provision or } \\
\text { related activities. }\end{array}$ & $\begin{array}{l}\text { 1. Why use this indicator? To identify the } \\
\text { indirect impacts of urban infrastructure } \\
\text { procurement. } \\
\text { 2. Key sources of information: key informants, } \\
\text { project files. } \\
\text { 3. How to determine the indicator: interviews } \\
\text { and review of available documentation. }\end{array}$ \\
\hline
\end{tabular}




\begin{tabular}{|l|l|}
\hline $\begin{array}{l}\text { The economic impacts of the infrastructure } \\
\text { provision through community partnered } \\
\text { procurement }\end{array}$ & $\begin{array}{l}\text { 1. } \begin{array}{l}\text { Why use this indicator? To identify and assess } \\
\text { the indirect impacts of urban infrastructure } \\
\text { procurement. }\end{array} \\
\text { Key sources of information: key informants } \\
\text { and survey. }\end{array}$ \\
$\begin{array}{l}\text { How to determine the indicator: interviews } \\
\text { with key personnel. }\end{array}$ \\
\hline
\end{tabular}

\begin{tabular}{|c|c|}
\hline $\begin{array}{l}\text { The duration of employment and wage rates as } \\
\text { compared to the market rates. }\end{array}$ & $\begin{array}{l}\text { 1. Why use this indicator? To identify and } \\
\text { monitor any exploitation of the community. } \\
\text { 2. Key sources of information: survey, national } \\
\text { wage rate and project files. } \\
\text { 3. How to determine the indicator; review of } \\
\text { documents and interviews. }\end{array}$ \\
\hline The increase in the employment of women & $\begin{array}{l}\text { 1. Why use this indicator? To identify } \\
\text { improvements in equal opportunities. } \\
\text { 2. Key sources of information: project files and } \\
\text { key informants. } \\
\text { 3. How to determine the indicator: review of the } \\
\text { project documentation and interviews. }\end{array}$ \\
\hline $\begin{array}{l}\text { The increase in earnings from home or community } \\
\text { based activities? }\end{array}$ & $\begin{array}{l}\text { 1. Why use this indicator? To identify indirect } \\
\text { economic impact. } \\
\text { 2. Key sources of information: key informants. } \\
\text { 3. How to determine the indicator: interviews } \\
\text { with key informants. }\end{array}$ \\
\hline The increase in property values or rents? & $\begin{array}{l}\text { 1. Why use this indicator? To identify, evaluate } \\
\text { and monitor direct and indirect impacts of urban } \\
\text { infrastructure provision } \\
\text { 2. Key sources of information: surveys and key } \\
\text { informants. } \\
\text { 3. How to determine the indicator; interviews } \\
\text { with key informants. }\end{array}$ \\
\hline $\begin{array}{l}\text { Incidences of improvements in social relations due } \\
\text { to the process or the product of the infrastructure } \\
\text { procurement. }\end{array}$ & $\begin{array}{l}\text { 1. Why use this indicator? To identify, evaluate } \\
\text { and monitor direct and indirect impacts of urban } \\
\text { infrastructure provision } \\
\text { 4. Key sources of information: key informants. } \\
\text { 4. How to determine the indicator: interviews } \\
\text { with key informants. }\end{array}$ \\
\hline $\begin{array}{l}\text { Incidences of time savings due to infrastructure } \\
\text { provision. }\end{array}$ & $\begin{array}{l}\text { 1. Why use this indicator? To identify, monitor } \\
\text { and evaluate the direct and indirect impacts of } \\
\text { urban infrastructure provision. } \\
\text { 2. Key sources of information: key informants. } \\
\text { 3. How to determine the indicator: interviews } \\
\text { with key informants. }\end{array}$ \\
\hline
\end{tabular}


Incidences of empowerment,

(including the ability to choose, access to the

1. Why use this indicator? To identify examples

officials, access to decision making process.)

2. Key sources of information: key informants and contract procedures.

3. How to determine the indicator: interviews with key informants and a review of the project documentation. 